\title{
Evaluation of Receptor Affinity, Analgesic Activity and Cytotoxicity of a Hybrid Peptide, AWL3020
}

\author{
Joanna Matalińska ${ }^{1}$ (D) Piotr F. J. Lipiński ${ }^{1}$ (D) Agnieszka Kotlarz ${ }^{2} \cdot$ Piotr Kosson $^{3} \cdot$ Adriana Muchowska $^{1} \cdot$ \\ Jolanta Dyniewicz ${ }^{1}$
}

Accepted: 11 February 2020 / Published online: 19 February 2020

(c) The Author(s) 2020

\begin{abstract}
In the present contribution we report design, synthesis and evaluation of receptor affinity, analgesic activity and cytotoxicity of a hybrid peptide, AWL3020. The peptide includes two pharmacophores, one of $\delta$-opioid receptor ( $\delta \mathrm{OR})$ agonists and one of neurokinin-1 receptor (NK1R) antagonists. The design was motivated by the desire to obtain a compound with strong analgesic action and potential additional antiproliferative action. The compound displays high $\delta \mathrm{OR}$ affinity $\left(\mathrm{IC} \mathrm{C}_{50}=29.5 \mathrm{nM}\right)$. On the other hand, it has only poor affinity for the NK1R $\left(\mathrm{IC}_{50}=70.28 \mu \mathrm{M}\right)$. The substance shows good analgesic action which is however weaker than that of morphine. Regarding the effect on proliferation, the compound exhibits no pro-proliferative action in the assayed range. In higher concentrations, it has also cytotoxic activity. This effect is however not selective. The strongest effect of AWL3020 was found for melanoma MeW164 cell line $\left(\mathrm{EC}_{50}=46.27 \mu \mathrm{M}\right.$ in reduction of cell numbers after a few days of incubation; $\mathrm{EC}_{50}=37.78 \mu \mathrm{M}$ in MTT assay).
\end{abstract}

Keywords Cancer pain $\cdot$ Multitarget drugs $\cdot$ Neurokinin-1 receptor $\cdot$ Delta opioid receptor

\section{Introduction}

Electronic supplementary material The online version of this article (https://doi.org/10.1007/s10989-020-10051-5) contains supplementary material, which is available to authorized users.

Joanna Matalińska

jmatalinska@imdik.pan.pl

$\triangle$ Piotr F. J. Lipiński

plipinski@imdik.pan.pl

Agnieszka Kotlarz

akotlarz@coi.waw.pl

Piotr Kosson

pkosson@imdik.pan.pl

Adriana Muchowska

amuchowska@imdik.pan.pl

Jolanta Dyniewicz

jdyniewicz@imdik.pan.pl

1 Department of Neuropeptides, Mossakowski Medical Research Centre, Polish Academy of Sciences, 02-106 Warsaw, Poland

2 Maria Sklodowska-Curie Memorial Institute and Oncology Centre, 02-781 Warsaw, Poland

3 Toxicology Research Laboratory, Mossakowski Medical Research Centre, Polish Academy of Sciences, 02-106 Warsaw, Poland
Various types of cancers are among the most important problems of modern medicine. Cancer is often difficult to treat and its progression is frequently accompanied by pain (Portenoy and Ahmed 2018). In particular, pain is most problematic in advanced stages of the disease. Pain seems to be a key factor contributing to the lowering of patients' quality of lives.

Current treatment of cancer pain relies mostly on opioids like morphine, fentanyl, buprenorphine, tramadol and others (Money and Garber 2018). Many ways of administrations are available for the opioids including oral, transdermal, transmucosal or via enteral tubes. Unfortunately, these therapies are far from ideal. In many cases, they lack enough efficacy in relieving pain and their prolonged use causes tolerance. The opioids can also have unpleasant or even life-threatening side-effects (Benyamin et al. 2008), which include: nausea, vomiting, constipations and respiratory depression. Recently, there are also some reports that opioids can stimulate growth of cancer cells and induce progression of cancers (Lazarczyk et al. 2010; Lennon et al. 2012; Nguyen et al. 2014; Bimonte et al. 2015; Aich et al. 2016). Other papers bring contradicting 
conclusions (Chen et al. 2017). The matter is subject of ongoing research summarized in several recent reviews (Zhang et al. 2018; Brinkman et al. 2018; Chen et al. 2019a; Tuerxun and Cui 2019).

Nevertheless, an ideal antipain drug for the treatment of cancer pain should be a strong analgesic, without significant side-effects and without stimulatory effects on the development of cancer. Optimally it could also have some anticancer activity on its own. In this way, it could positively cooperate with the main therapy. With these assumptions in mind, we have endeavoured to find analgesic peptides with auxiliary anticancer properties. To this aim, we have designed a hybrid peptide (named AWL3020, Fig. 1) consisting of two pharmacophores, one of $\delta$-opioid receptor ( $\mathrm{OOR}$ ) agonists and one of neurokinin-1 receptor (NK1R) antagonists. The opioid sequence (Tyr-D-Ala-Phe-His-LeuLeu-Asp...) was taken from a well-known $\delta \mathrm{OR}$ agonist, $\left[\mathrm{D}-\mathrm{Ala}^{2}, \mathrm{Leu}^{6}\right]$-deltorphin (Janecka et al. 2004). The neurokinin-1 antagonist sequence (...D-Phe-Phe-D-Phe-LeuLeu- $\mathrm{NH}_{2}$ ) was that of a peptidic NK1R antagonist, spantide I (Gether et al. 1993), with two conservative exchanges of D-Trp for D-Phe. The design of AWL3020 was based on the following rationale. First, $\delta \mathrm{OR}$ agonists are strong analgesic agents (Gavériaux-Ruff and Kieffer 2011). Second, hybridization of opioid agonist and NK1R antagonist pharmacophores produces analgesic molecules with reduced tolerance and side-effects (Largent-Milnes et al. 2010). Third, NK1R antagonists have been shown to have anticancer activity in vitro and in vivo (Harford-Wright et al. 2013; Garnier et al. 2015; Muñoz and Coveñas 2016).

In this paper, we report the pharmacological effects of AWL3020 in several in vitro and in vivo experiments that were aimed at validating the design rationale. First, we assayed AWL3020 for receptor affinities. Having found high affinity for the $\delta \mathrm{OR}$, we performed molecular modelling of the compound bound to this receptor and assessed in vivo its analgesic activity. Finally, we comprehensively assessed the cytotoxicity of the compound against several cancer and normal cell lines.

\section{Materials and Methods}

\section{AWL 3020 Synthesis}

Compound AWL3020 was synthesized by the use of a modified method described previously (Laskowska et al. 2017). The synthesis was performed on solid support (SPPS), following a typical protocol, on the Rink amide resin and with HOBt/TBTU coupling reagents. The cleavage of peptide from the resin was conducted by using trifluoroacetic acid. Its mass was confirmed by mass spectrometry $\left(\mathrm{C}_{82} \mathrm{H}_{109} \mathrm{~N}_{15} \mathrm{O}_{15}\right.$, MW: $1544.834 \mathrm{u}$, monoisotopic mass $1543.82 \mathrm{u}$, ESI-MS ion found $\mathrm{m} / z[\mathrm{M}+2 \mathrm{H}]^{2+} 772.90$, calculated $[\mathrm{M}+2 \mathrm{H}]^{2+} 772.82$ ). The purity of the preparation was found to be greater than $98 \%$ by using HPLC with UV/ VIS detector $\left(t_{R}=11.7\right.$ min, linear gradient $3-97 \%$ of phase $\mathrm{B}$ in 20 min, phase $\mathrm{A}: 0.05 \%$ aq. $\mathrm{FA}$, phase $\mathrm{B}: \mathrm{ACN}+0.05 \%$ FA, total flow rate: $1.2 \mathrm{ml} / \mathrm{min}$ ). The chromatograms and the mass-spectrum are given in the Supplementary Materials in Figures ESM-CHEM-1 to ESM-CHEM-3.

\section{Receptor Binding Assays}

The binding affinity of compound AWL3020 for $\mu \mathrm{OR}, \delta \mathrm{OR}$ and NK1R was determined in competitive radioligand binding assays using rat brain homogenates.

The membrane fractions containing the receptors were obtained from rats euthanized by decapitation after which an immediate brain removal, separation of cerebellum and placement of the remaining brain in an ice-cold $50 \mathrm{nM}$ Tris- $\mathrm{HCl}$ (pH 7.4) was conducted. Brain tissue was subject to homogenization with up-down strokes in a hand glass homogenizer and suspended in 20 Tris- $\mathrm{HCl}$ volumes. A

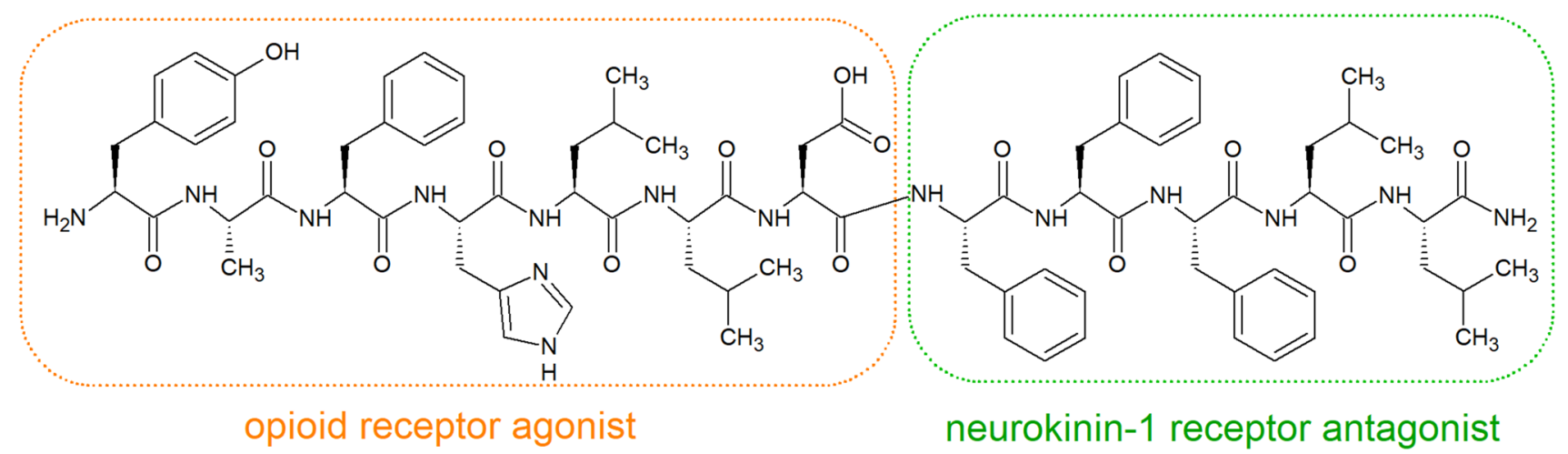

Fig. 1 Structure of compound AWL3020. The dotted boxes enclose pharmacophoric structural elements for opioid (orange) and neurokinin-1 receptors (green) (Color figure online) 
centrifugation of the homogenate (at $23.000 \mathrm{rpm}$ at $4{ }^{\circ} \mathrm{C}$ for $15 \mathrm{~min}$ ) enabled the disposition of the unnecessary supernatant. The precipitate was resuspended in Tris- $\mathrm{HCl}$ buffer and incubated at $25^{\circ} \mathrm{C}$ for $30 \mathrm{~min}$. The centrifugation and resuspension were repeated again, whereafter the preparation was put to be stored at $-20{ }^{\circ} \mathrm{C}$ for later use.

The membrane preparations were incubated at $25{ }^{\circ} \mathrm{C}$ for $60 \mathrm{~min}$ in the presence of radioligands (in $0.5 \mathrm{nM}$ concentration) specific for each assayed receptor $\left(\mu \mathrm{OR}:\left[{ }^{3} \mathrm{H}\right] \mathrm{DAMGO}\right.$,

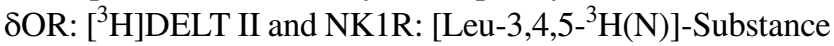
$\mathrm{P}$, all obtained from PerkinElmer, USA) and the increasing concentrations of the assayed compound $\left(10^{-11}\right.$ up to $10^{-4} \mathrm{M}$, each concentration in duplicate). Non-specific binding was measured in the presence of either $10 \mu \mathrm{M}$ naloxone (opioid receptors) or $10 \mu \mathrm{M}$ Substance P (NK1R). The assays were conducted with the assay buffer made of $50 \mathrm{mM}$ Tris- $\mathrm{HCl}$ (pH 7.4), bovine serum albumin (BSA) $(0.1 \mathrm{mg} / \mathrm{ml})$, bacitracin $(100 \mu \mathrm{g} / \mathrm{ml})$, bestatin $(30 \mu \mathrm{M})$ and captopril $(10 \mu \mathrm{M})$ in a total volume of $1 \mathrm{ml}$. Following the incubation, a rapid filtration with a M-24 Cell Harvester (Brandel/USA) through GF/B Whatman glass fiber strips was done. The filters were soaked with $0.5 \%$ PEI just before being used for harvesting (for opioid receptors) or pre-soaked for $3 \mathrm{~h}$ (in the case of NK1R) so as to minimize the extent of non-specific binding. Filter discs were placed separately in 24-well plates and an Optiphase Supermix scintillation solution (Perkin Elmer, USA) was added to each well. Radioactivity was measured in a scintillation counter MicroBeta LS, Trilux (PerkinElmer, USA). Displacement curves were drawn and the mean $\mathrm{IC}_{50}$ values were determined with SEMs (GraphPad Prism version 5.0, San Diego CA).

The experiments were performed in duplicate.

\section{Molecular Modelling}

AWL3020 was docked to the $\delta$ OR (PDB accession code: 4RWD (Fenalti et al. 2015)) by using AutoDock 4.2 (Morris et al. 2009). The protonation states of the residues (in the peptide and in the receptor) were set as expected at physiological $\mathrm{pH}$. Other preparatory steps were performed in AutoDock Tools 4 and AutoGrid 4 (Morris et al. 2009). The docking box was set around the ligand found in the structure (H-Dmt-Tic-Phe-Phe- $\mathrm{NH}_{2}$ ), but extended so that it encompassed the cavity up to the receptor outlet and slightly further.

\section{Animals}

The rats (of 200-250 g weight, 10 animals for each test group and for control group) were prepared for the i.t. administration by a method described by Yaksh and Rudy (1976). The animals were anaesthetised with isoflurane (Forane, USP, Baxter) and placed in a stereotaxic device.
Into their intrathecal space implanted were silicone tubing catheters (ID $=0.30 \mathrm{~mm}$ and $\mathrm{OD}=0.64 \mathrm{~mm}$, length $=12 \mathrm{~cm}$, Silastic Laboratory Tubing, Dow Corning Corporation) with the tip located at L1 spinal level. At about $2 / 3$ of its length it contains a silicone limiter in a form of a ball which prevents undesired displacements of the device. After the surgery and waking up from anaesthesia, the rats were given 2-3 days for recovery. They were housed in individual cages in a temperature- and light-controlled environment $(12 \mathrm{~h} / 12 \mathrm{~h}$ day/ night cycle), with food and water ad libitum. Rats that suffered with plegia after the catheterisation were excluded from further experimental procedures.

All housing and experiments were conducted in accordance with the Polish Act of 21 January 2005 on Experiments on Animals (Journal of Laws No 33 of the Republic of Poland, item 289 as amended). All animal experiments were approved by the IV Local Ethics Committee for Experiments on Animals in Warsaw, Poland (permissions no.: 46/2013). All efforts were made to minimize the number of animals used and their suffering.

\section{Tail-Flick Test After Intrathecal Drug Administration}

The analgesic activity of compound AWL3020 was measured in vivo in adult male Wistar Rats by a tail-flick test after intrathecal (i.t.) administration.

The compounds under consideration (AWL3020 and morphine) were dissolved in a small amount of DMSO and then the saline was added so to obtain a solution with DMSO concentration not greater than $10 \%$. They were administered via the above mentioned catheters in a total volume not exceeding $10 \mu \mathrm{l}$. Control animals received saline solution (Polfa). For the sake of comparison with a 'gold standard' treatment, another control group received a solution of morphine. Both the test and the control groups consisted of at least five animals.

Analgesia was quantified by the means of the Plantar Test and Tail Flick Analgesia Meter apparatus (IITC Life Science Inc.). The rats were gently restrained and a radiant heat beam was projected onto the dorsal side of the tail at cca $1 / 3 \mathrm{rd}$ of its length. The latency time before the tail withdrawal was measured by a built-in timer. The thermal stimulus was reapplied three times at $10 \mathrm{~s}$ intervals. The temperature of the beam was adjusted so that the baseline response was approximately $2 \mathrm{~s}$. If a rat (not having been administered a test compound) exhibited the baseline response of more than $4 \mathrm{~s}$, it was excluded from further experiments. For the purpose of avoiding tail burns the apparatus was not allowed to emit the beam for more than $7 \mathrm{~s}$. Rats' struggling or ambulation were considered as ambiguous responses and if present, the measurements were repeated.

The measurements were performed before the compound administration, as well as 5, 15, 30, 60 and 120 min after the 
administration. Each measurement was repeated three times with some minor changes to the place where the beam fell on the tail.

The analgesia level was calculated for each time point and expressed as a maximum possible effect (\% MPE) according to the Brady and Holtzmann formula (Brady and Holtzman 1982):

$\% M P E=100 \% * \frac{\text { postdrug latency }- \text { predrug latency }}{\text { maximum latency }(7 s)-\text { predrug latency }}$

\section{Cell Cultures}

Human melanoma cell lines MeW151, MeW155, MeW164, human lung cancer E14, urinary bladder carcinoma cell line T24, and also normal adult human fibroblast cell lines Fib9 and FlW180 and human foetal fibroblast cell line FlWp95 were obtained from the institutional cell bank at the Maria Sklodowska-Curie Memorial Institute and Oncology in Warsaw. The T24 line was generously gifted by Prof. Georg Klein from the Karolinska Institute in Stockholm (Bubeník et al. 1973).

All the lines were cultured in Eagle's 1959 MEM medium (Biomed, Lublin, Poland) with addition of $10 \%$ foetal calf serum (Invitrogen), $50 \mu \mathrm{g} / \mathrm{ml}$ penicillin $\mathrm{G}, 50 \mu \mathrm{g} / \mathrm{ml}$ streptomycin, and $0.1 \%$ glutamine. All the cell lines were kept at $37^{\circ} \mathrm{C}$, under humidified atmosphere containing $5 \% \mathrm{CO}_{2}$.

\section{Cell Proliferation Assay}

The cells were plated in 24-well plates (5000 cells per well). After two hours (with the cells adhered to the well bottoms), the compound AWL3020 was added to the wells in the range of concentrations. These were: $100 \mu \mathrm{M}, 50 \mu \mathrm{M}, 25 \mu \mathrm{M}$ for all cell lines; and additionally for MeW151 and MeW164: $10 \mu \mathrm{M}, 5 \mu \mathrm{M}, 2.5 \mu \mathrm{M}, 1 \mu \mathrm{M}$. The control consisted of wells where the cells were untreated with AWL3020 (only the assay medium was added).

The cells were incubated (in the presence of AWL3020 or without it for control) for:

\section{a. 4 days (cancer cells), \\ b. 7 days (normal cells).}

The incubation times were set this way so that the cells be de-attached at the state of sub-confluency. After the incubation, the cells were de-attached by using $0.25 \%$ trypsin with EDTA $(200 \mathrm{mg} / \mathrm{l})$. The cells were counted in haematocytometer under a microscope. The dead cells were stained with the trypan blue. Two independent experiments (each data point in three repetitions) were performed.

\section{MTT assay}

Cell viability was assessed by the MTT ((3-(4,5-dimethylthiazolyl-2)-2,5-diphenyltetrazolium bromide) colorimetric assay which is based on the direct measure of mitochondrial activity. The MTT assay was performed following the method proposed by the American Type Culture Collection (ATCC), catalogue number 30-1010K (Collection ATC MTT Cell Proliferation Assay Instruction Guide 2016). The cells were seeded in 96-well plates (5000 cells per well). The culture medium was RPMI-1640 (Gibco) with 10\% foetal calf serum (Invitrogen). After two hours (with the cells adhered to the well bottoms), the compound AWL3020 was added to the wells in the range of concentrations. These were: $100 \mu \mathrm{M}, 50 \mu \mathrm{M}, 25 \mu \mathrm{M}$ for all cell lines; and additionally for MeW151 and MeW164: $10 \mu \mathrm{M}$, $5 \mu \mathrm{M}$ and $2.5 \mu \mathrm{M}$. The control consisted of wells where the cells were untreated with AWL3020. After a 24-h incubation (in the presence of AWL3020 or without it), the tetrazolium salt (MTT) was added to the wells. The plates were then kept at $37^{\circ} \mathrm{C}$. Four hours later, the detergent was added (according to the ATCC protocol), and the plates were stored in the dark for two hours at room temperature. Then, the absorbance was read at $570 \mathrm{~nm}$ by using HR 7000 spectrophotometer (Hamilton). The absorbance values are proportional to the number of viable cells. Two independent experiments (each data point in three repetitions) were performed.

\section{Colony Formation Assay}

Cancer cells (100 cells per dish) were seeded on Petri dish (diameter: $2.5 \mathrm{~cm}$ ). After two hours, AWL3020 was added to the dishes in certain concentrations. These were: $100 \mu \mathrm{M}$, $50 \mu \mathrm{M}$ and $25 \mu \mathrm{M}$. The cells were incubated for 7 days. Then, the cultures were rinsed with PBS and dyed with crystal violet. After $20 \mathrm{~min}$, the dishes with stained cells were rinsed with distilled water. The number of colonies formed were counted under the microscope. The experiment was repeated twice with three replicates. The control consisted in cells without the addition of AWL3020.

\section{Evaluation of Ki-67 Expression}

Expression of the Ki-67 protein was evaluated because this protein is a marker for proliferating cells, as it is present in the cell during all phases of the cell cycle $\left(\mathrm{G}_{1}, \mathrm{~S}, \mathrm{G}_{2}, \mathrm{M}\right)$, but it is undetectable with the resting state $\left(\mathrm{G}_{0}\right.$ phase $)$. The cells (5000 cells per well) were seeded on coverslips $(12 \mathrm{~mm}$, Life Sciences) located in 24-well plates. After two hours, the compound AWL3020 was added in a few concentrations. These were: $100 \mu \mathrm{M}, 50 \mu \mathrm{M}, 25 \mu \mathrm{M}$. The plates were incubated for 4 days. After that time, the cells were rinsed three times with PBS and then fixed with 4\% paraformaldehyde (PFA, $15 \mathrm{~min}$, at room temperature). After another rinsing with 
PBS $(3 \times 5 \mathrm{~min})$, a permeabilising mixture $(0.25 \%$ Triton in PBS) was added to the cells and left for $15 \mathrm{~min}$ at room temperature. For the sake of minimising unspecific binding, a blocking mixture (10\% GS Goat Serum in PBS) was added. After an hour, the cells were treated with the primary Ki-67 antibody (dilution 1:500, IgG1 Novocastra/Leica). The cells were left overnight at $4{ }^{\circ} \mathrm{C}$. After rinsing the cells with PBS $(3 \times 5 \mathrm{~min}$ ), the secondary antibody Alexa Fluor 546 (dilution 1:1000, Anti-Mouse IgG Invitrogen) was added and the cells were left in the dark for another hour. Then, another rinsing with PBS was performed and Hoechst 33,258 staining dye (dilution 1:150, in PBS, 5 min, in the dark) was added. The dyed and fixed cells were counted under inverted microscope Eclipse Ni-U (Nikon). The proliferation index was the percent of cells exhibiting Ki-67 expression in randomly selected populations. Two independent experiments (each data point in three repetitions) were performed. In each experiment, the counting was performed on 10 views.

\section{Statistical Analysis}

Quantitative data from the experiments are expressed as the mean \pm standard deviation (S.D., cellular assays) or standard error of the mean (SEM, binding affinity and in vivo analgesic activity). Statistical analyses were performed by analysis of variance (ANOVA) with post-hoc Dunnett test when comparing against the control values or with Tukey's multiple comparisons test when comparing groups against each other (at significance level $\alpha=0.05$ ). Statistical tests and curve fitting were performed by using GraphPad Prism version 7.0.2 for Windows, GraphPad Software, San Diego, California USA, www.graphpad.com.

\section{Results}

\section{Receptor Binding Affinity}

In order to validate the design rationale for AWL3020, we have first evaluated receptor binding affinity of the compound for $\mu$ - and $\delta O R s$, as well as for the NK1R. The affinity was determined in a radioligand displacement binding assay. The displacement curves are given in Fig. 2. Half-maximal inhibitory concentration $\left(\mathrm{IC}_{50}\right)$ is provided in Table 1.

AWL3020 binds very well $8 \mathrm{OR}$ with $\mathrm{IC}_{50}$ being $29.5 \mathrm{nM}$. On the contrary, it has a significantly lower affinity for the $\mu$-opioid receptor, for which its $\mathrm{IC}_{50}$ reads $1070 \mathrm{nM}$. Even poorer $\mathrm{IC}_{50}$ value is found in the case of the NK-1 receptor $\left(\mathrm{IC}_{50}=70,280 \mathrm{nM}\right)$.
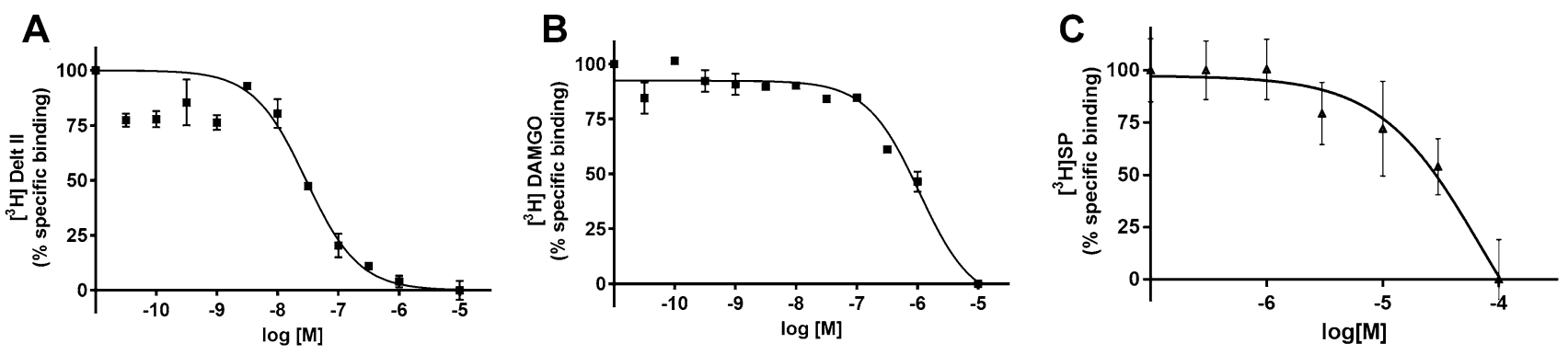

Fig. 2 Radioligand displacement curves for AWL3020 binding to $\mathbf{a} \delta$-opioid receptors $\mathbf{b} \mu$-opioid receptors $\mathbf{c}$ neurokinin- 1 receptors

Table 1 Half-maximal inhibitory concentration $\left(\mathrm{IC}_{50}\right)$ for AWL3020 receptor binding. For comparison given are also $\mathrm{IC}_{50}$ values of reference opioid and neurokinin-1 receptors ligands obtained in our laboratory

\begin{tabular}{|c|c|c|c|c|c|c|}
\hline & $\mu \mathrm{OR}$ & & $\delta \mathrm{OR}$ & & NK1R & \\
\hline \multicolumn{7}{|c|}{ Tested compound } \\
\hline & $\log \mathrm{IC}_{50} \pm \mathrm{SEM}$ & $\mathrm{IC}_{50}^{1}$ & $\operatorname{Log~IC}_{50} \pm \mathrm{SEM}$ & $\mathrm{IC}_{50}^{1}$ & $\log \mathrm{IC}_{50} \pm \mathrm{SEM}$ & $\mathrm{IC}_{50}^{1}$ \\
\hline AWL3020 & $-5.97 \pm 0.10$ & 1070 & $-7.53 \pm 0.10$ & 29.5 & $-4.15 \pm 0.25$ & 70,280 \\
\hline \multicolumn{7}{|c|}{ Reference opioids } \\
\hline Morphine & $-8.46 \pm 0.07^{2}$ & $3.5^{2}$ & $\mathrm{n} / \mathrm{d}$ & & $\mathrm{n} / \mathrm{d}$ & \\
\hline Biphalin & $-8.82 \pm 0.12^{2}$ & $1.5^{2}$ & $-7.54 \pm 0.13^{2}$ & $29.0^{2}$ & ndb & \\
\hline \multicolumn{7}{|c|}{ Reference NK1R ligands } \\
\hline Substance P & $\mathrm{n} / \mathrm{d}$ & & $\mathrm{n} / \mathrm{d}$ & & $-8.94 \pm 0.13^{2}$ & $1.1^{2}$ \\
\hline Aprepitant & $\mathrm{n} / \mathrm{d}$ & & $\mathrm{n} / \mathrm{d}$ & & $-6.63 \pm 0.13^{2}$ & $236.5^{2}$ \\
\hline
\end{tabular}

$n / d$ not determined, $n d b$ no detectable binding at $10^{-4} \mathrm{M}$

${ }^{1} \mathrm{IC}_{50}$ values are given in $\mathrm{nM}$

${ }^{2}$ Unpublished results 
Thus AWL3020 is a relatively strong $\delta$ OR ligand, of similar affinity as a reference peptidic biphalin whose $\mathrm{IC}_{50}$ is $29.0 \mathrm{nM}$. In the case of $\mu \mathrm{OR}$ binding, the affinity of AWL3020 is low, compared to both the peptidic biphalin as well as prototypical alkaloid morphine. This opioid profile is in fact not unexpected as the sequence of AWL3020 in the opioid part stems from a selective $\delta$ OR peptide, [D-Ala ${ }^{2}$, $\mathrm{Leu}^{6}$ ]-deltorphin (Janecka et al. 2004).

What is surprising, AWL3020 exhibits only very poor NK1R affinity. It is more than 4 orders of magnitude lower than that of the reference peptidic Substance P $\left(\mathrm{IC}_{50}=1.1 \mathrm{nM}\right)$ and more than two orders of magnitude lower than that of a small molecular antagonist, aprepitant $\left(\mathrm{IC}_{50}=236.5 \mathrm{nM}\right)$.

\section{Molecular Modelling}

A probable structural basis for high affinity of AWL3020 for $\delta \mathrm{OR}$ is provided by molecular modelling. The highest ranked binding mode is presented in Figs. 3 and 4. The first of the Figures contains a detailed depiction of the contacting receptor residues.

According to the modelling analysis, AWL3020 enters deeply into the binding pocket with the opioid sequence (the $\mathrm{N}$-terminal part) towards the receptor interior. The antitachykinin part (from the 7 th position to the C-terminus) locates near the receptor outlet. Let us note here that as the receptor structure used for docking does not contain the N-terminus of the receptor, it is impossible to discuss potential interactions of the tachykinin sequence with the opioid receptor.

Regarding the opioid part of the ligand, it is anchored in the receptor by the canonical charge-assisted hydrogen bond formed by the protonated amine of $\mathrm{Tyr}^{1}$ with D128. The tyrosine's side chain contacts a few hydrophobic amino acids of the binding pocket bottom, including e.g. I277, M132, W274, V281, V217 and F218. Relatively closely located is also H278. The Phe ${ }^{3}$ is surrounded by side-chains of K214, F202 and L200. As to $\mathrm{His}^{4}$, it forms hydrophobic interactions with W284. The contacts of Leu ${ }^{5}$ and $\mathrm{Leu}^{6}$ include K108, Y109 and L48, V297, H301, respectively. The last amino acid of the opioid sequence, the charged $\mathrm{Asp}^{7}$ side chain is predicted to be situated closely to R291 (although our docking results do not show a charge-charge interaction between these two). Nevertheless, given that the receptor structure was rigid in our study, such contact cannot be excluded if receptor side-chains would be considered.

Comparing the obtained binding mode of AWL3020 with the one found experimentally for DIPP- $\mathrm{NH}_{2}$, (H-DmtTic-Phe-Phe- $\mathrm{NH}_{2}$, 4RWD PDB structure (Fenalti et al. 2015, Fig. 4c, d), it is found that both have the abovementioned canonical interaction, amine...D128. However, in AWL3020, the $\mathrm{Tyr}^{1}$ is displaced 'down' towards TM5

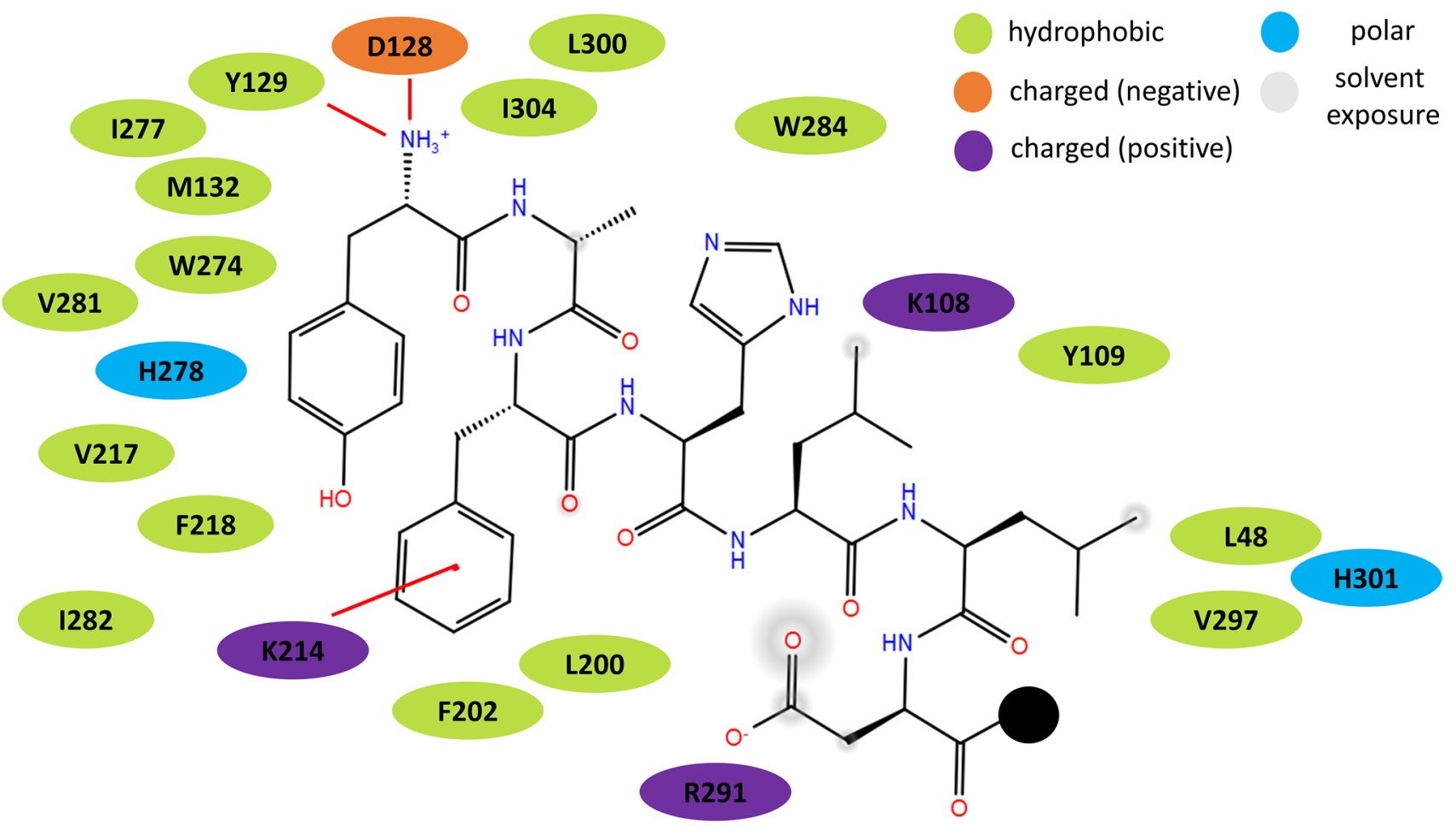

Fig. 3 Scheme of the interactions of AWL3020 with $\delta$-opioid receptor (docking with the use of 4RWD PDB structure (Fenalti et al. 2015)) as found by molecular docking. Presented is the opioid part of the compound. The black dot represents the tachykinin part of the compound omitted for clarity. Colours of the receptor residues are explained in the legend (Color figure online) 


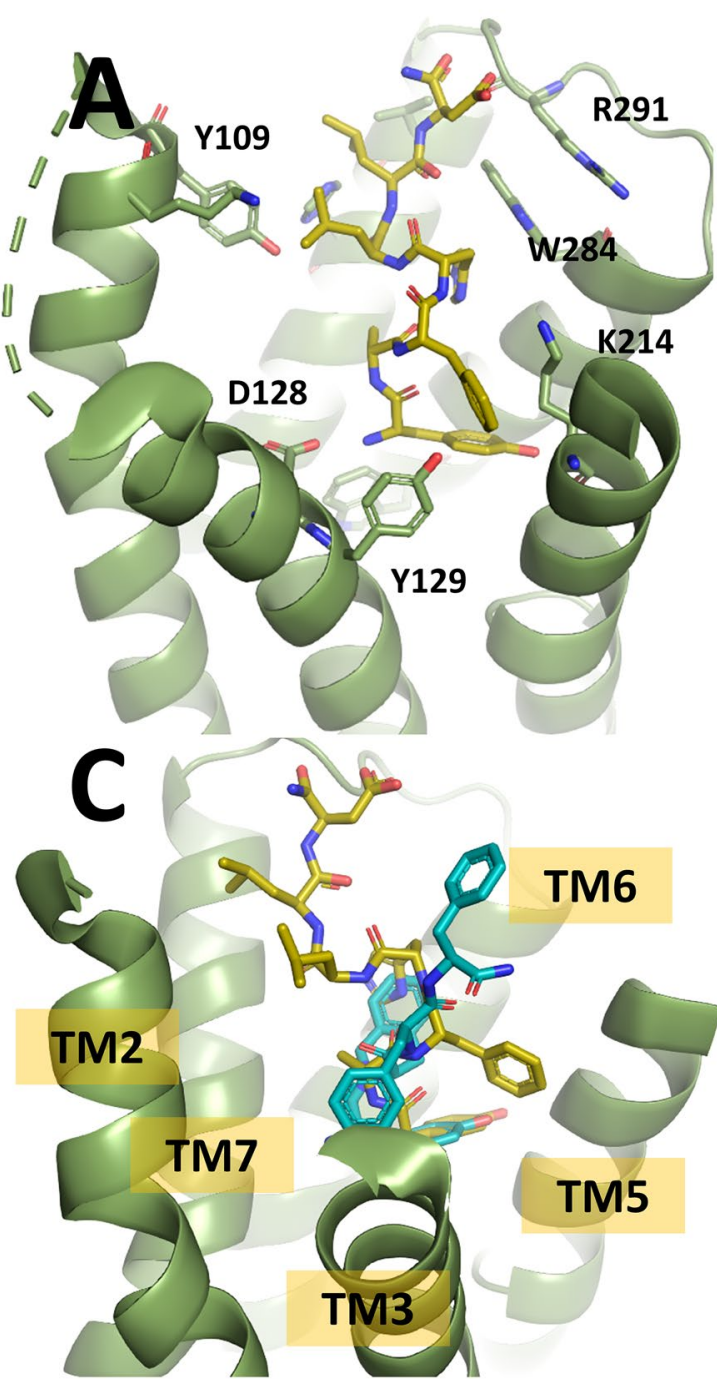

Fig. 4 Binding mode of AWL3020 in the $\delta$-opioid receptor as predicted by molecular docking. The peptide is shown as yellow sticks. Only the opioid part of the sequence is shown. The receptor (simplified view) is presented as green helices. Selected residues are shown as green sticks. Heteroatoms in both the peptide and the receptor are coloured as follows: blue nitrogen and red oxygen. TM stands

compared to Dmt ${ }^{1}$ of DIPP-NH ${ }_{2}$. Phe ${ }^{3}$ of both compounds are located in completely different subpockets. In the case of AWL3020, it is directed to TM5, while in the DIPP- $\mathrm{NH}_{2}$ the aromatic ring points to TM3 of the receptor. Interestingly, a partial overlap is predicted for $\mathrm{Tic}^{2}$ residue of DIPP- $\mathrm{NH}_{2}$ with $\mathrm{His}^{4}$ of AWL3020.

\section{In Vivo Analgesic Effects}

The compound AWL3020 displayed high affinity for $8 \mathrm{OR}$, so it was tested for analgesic activity in the tail-flick test following intrathecal (i.t.) administration in rats. $\mathrm{NaCl}$ solution was used as a negative control, and a positive control consisted in

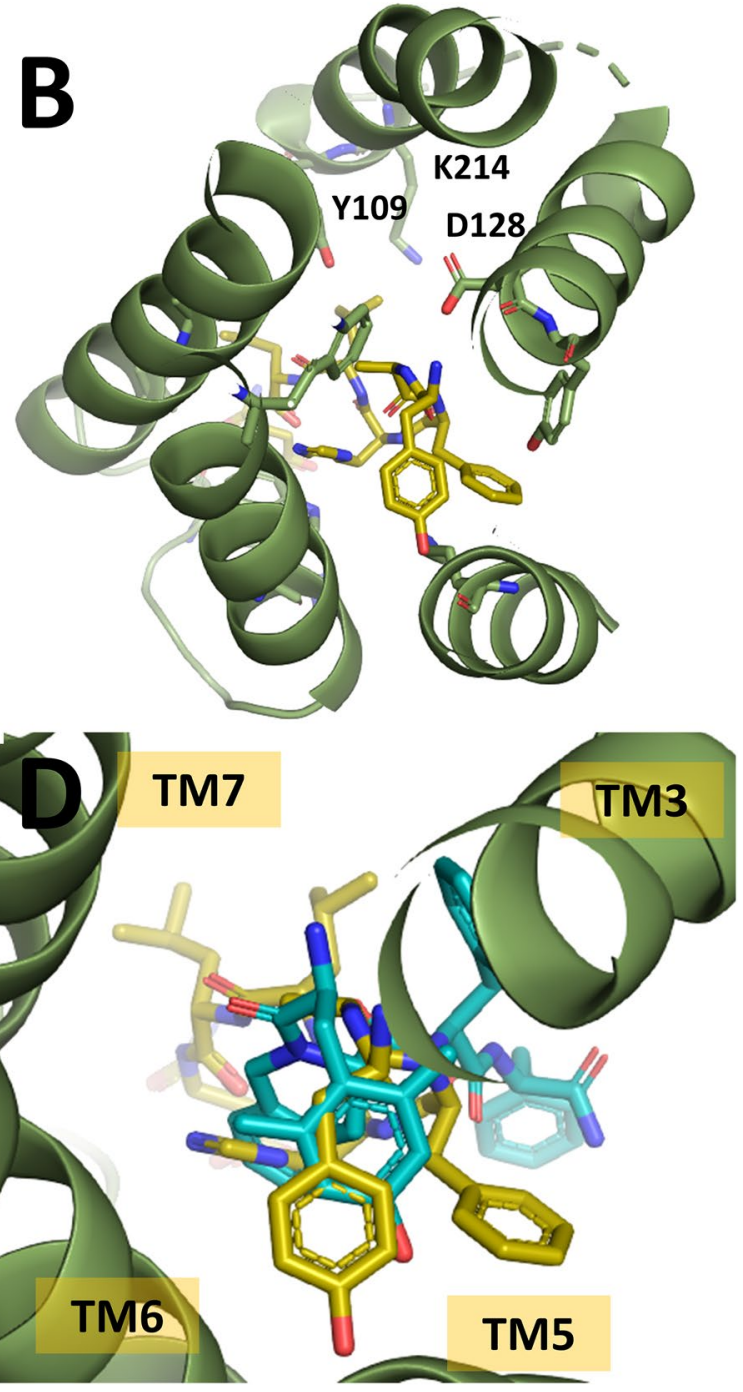

for transmembrane helix. a Side view of the peptide binding mode (receptor interior at the bottom). b A projection from the receptor interior. c Imposition of docked AWL3020 pose and the one found experimentally (4RWD PDB structure (Fenalti et al. 2015)) for DIPP$\mathrm{NH}_{2}$ (light blue sticks). d The imposition: a projection from the receptor interior (Color figure online)

morphine (the 'gold standard', $12 \mathrm{nmol} / \mathrm{kg}$ dose). The results are presented in graphical form in Fig. 5, and numerical data are given in Table ESM-ANALG-1. Consistent with its receptor affinity, the compound was found to have a strong time- and dose-dependent analgesic activity.

The compound was administered at doses of 10,40 and $60 \mathrm{nmol} / \mathrm{kg}$. The first of them was not able to produce analgesic effect greater than $45 \%$ of the Maximal Possible Effect (MPE) at any of the measured time points. At $40 \mathrm{nmol} / \mathrm{kg}$, the compound gave 53\% MPE after 5 min post injection. The peak effect (78.7\% MPE) was observed after $15 \mathrm{~min}$ and it lasted at a similar level also at $30 \mathrm{~min}$ post injection, with a minor drop (to $57.5 \% \mathrm{MPE}$ ) at $60 \mathrm{~min}$ post injection. This 


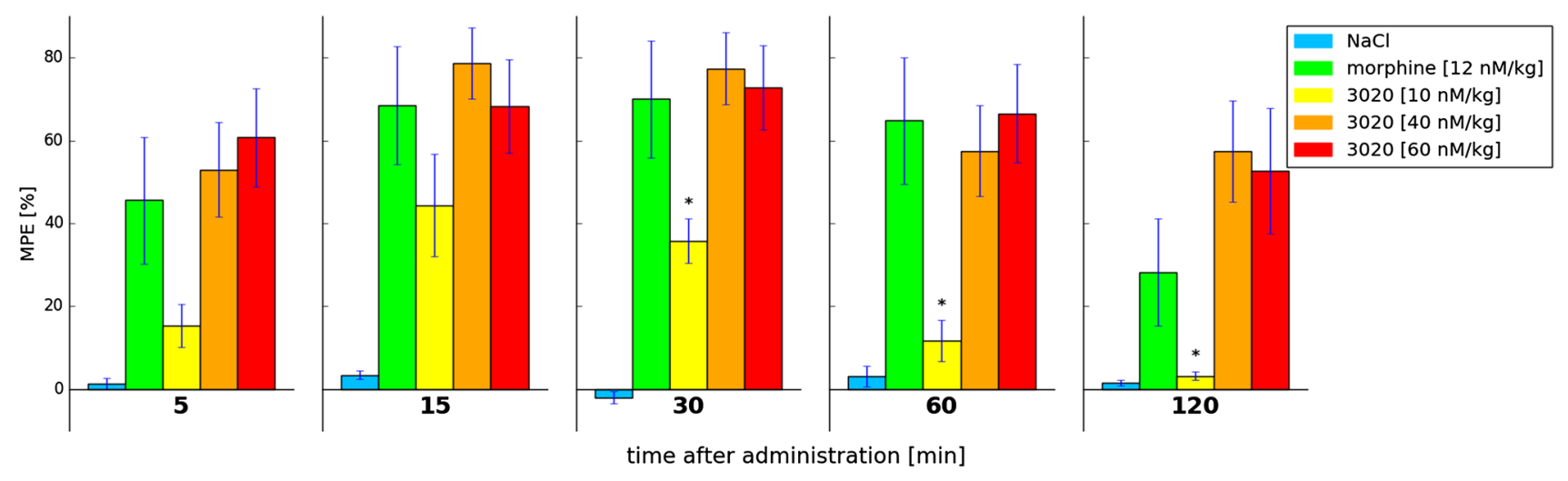

Fig. 5 Time and dose-dependence of analgesic response (i.t. administration, tail-flick test) of AWL3020 compared to negative $(\mathrm{NaCl})$ and positive (morphine $12 \mathrm{nmol} / \mathrm{kg}$ ) controls. Bar colouring corresponds to the concentration of AWL3020 as explained in the legend. Corresponding numerical values are given in Electronic Supplementary Materials in Table ESM-ANALG-1. Blue thin bar shows standard

level of analgesia persisted even $120 \mathrm{~min}$ after the injection. Increasing the dose $(60 \mathrm{nmol} / \mathrm{kg})$ did not have a statistically significant influence on the analgesic effect.

Comparing with the analgesic 'gold standard', morphine, compound AWL3020 seems a weaker analgesic. Analgesia equipotent to that obtained with i.t. administration of $12 \mathrm{nmol} / \mathrm{kg}$ morphine, requires dosing as much as $40 \mathrm{nmol} /$ $\mathrm{kg}$ AWL3020. This result is in agreement with receptor affinities. AWL3020 is a relatively strong $\delta O R$ ligand, however it has low affinity for $\mu \mathrm{OR}$. Therefore, morphine, a nanomolar $\mu \mathrm{OR}$ ligand, gives stronger analgesia compared to that compound.

\section{Cellular Pharmacological Effects in Cancer and Normal Cells}

The effects that AWL3020 has on cancer and normal cells were determined with regard to four aspects, that is with regard to:

a. direct effect on the number of cells following a few days of incubation,

b. cytotoxic effects as found in the MTT test,

c. effects on colony formation,

d. the impact on the cells proliferation as measured by determination of Ki-67 protein expression (proliferation index).

\section{Effect on the Number of Cells Following a Few Days of Incubation}

Eight cell lines ( 5 cancer and 3 normal ones) were incubated in the presence of $25-100 \mu \mathrm{M}$ of AWL3020. For two error of the mean. The asterisks denote statistical significance of the difference between the given value found for the given concentration and the control $(* \mathrm{P} \leq 0.05, * * \mathrm{P} \leq 0.01, * * * \mathrm{P} \leq 0.001)$. The statistical analysis used is the one-way ANOVA with post-hoc Dunnett test at significance level $\alpha=0.05$

melanoma cell lines, additional concentration set of the range $1-10 \mu \mathrm{M}$ was used. The results are graphically presented in Fig. 6 and the numerical data are given in Table ESM-CYTOX-1.

For all cell lines, a statistically significant effect on the number of cells is found at $100 \mu \mathrm{M}$ concentration. When $50 \mu \mathrm{M}$ concentration is considered, the effect is also present in all lines except for Fib9. Lower concentrations are effective only in MeW164 and MeW151 lines. For the experiments with the former, we have established $\mathrm{EC}_{50}$ value of $46.27 \mu \mathrm{M}$ (Figure ESM-CYTOX-1). Thus, it is this line that seems most sensitive to the incubation with AWL3020 with respect to the number of cells found after the multiday incubation. On the other hand, another melanoma cell line MeW155 is the least sensitive ( $74 \pm 1 \%$ of the control value). Similar low effect is found for FlW180 $(73 \pm 1 \%$ of the control value). The remaining lines are equally sensitive notwithstanding whether they are cancer or normal cell lines (no statistically significant difference between these 4 lines for values at $100 \mu \mathrm{M}$, Listing ESM-CYTOX-1). On average, these four lines exhibit $60 \pm 5 \%$ of the control value in the assay.

\section{Cytotoxic Effects in the MTT Test}

Cell viability of the AWL3020 compound was measured according to the MTT test. The assay readout is proportional to the number of metabolically active (alive) cells in the tested population. Here again, eight cell lines ( 5 cancer and 3 normal ones) were incubated in the presence of $25-100 \mu \mathrm{M}$ of AWL3020. For two melanoma cell lines, additional concentration set of the range $2.5 \mu \mathrm{M}-10 \mu \mathrm{M}$ was used. The 


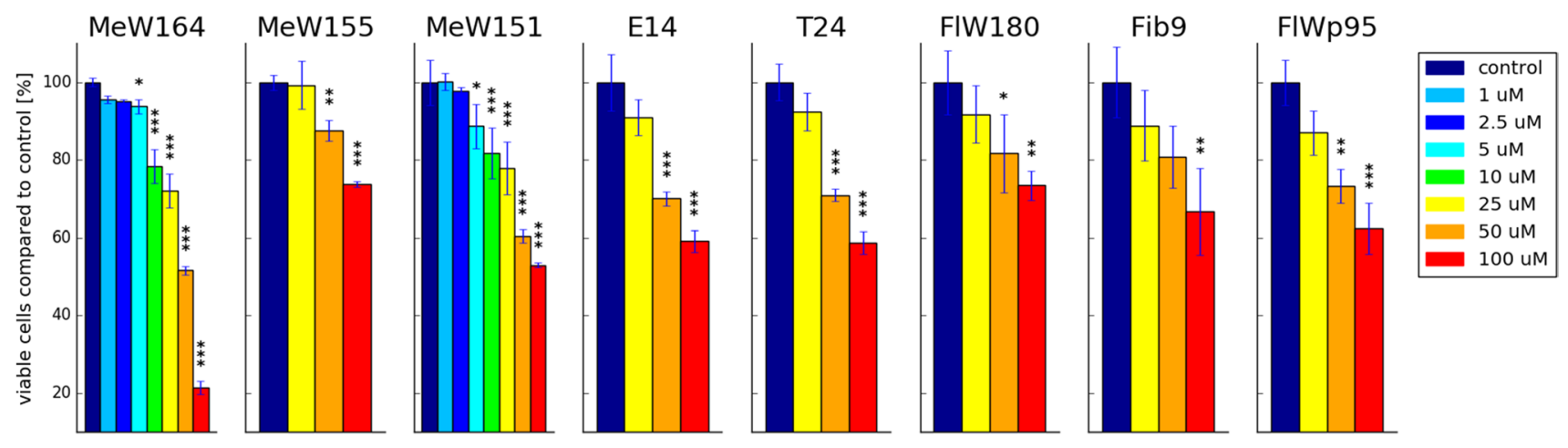

Fig. 6 The effect of AWL3020 on proliferation of different cell lines expressed as percentage of the values found for the control. Bar colouring corresponds to the concentration of AWL3020 as explained in the legend. Cell lines designations given in text. Corresponding numerical values are given in Electronic Supplementary Materials in Table ESM-CYTOX-1. Blue thin bar shows standard deviation. The data come from two independent experiments conducted in triplicate. The asterisks denote statistical significance of the difference between the given value found for the given concentration and the control $(* \mathrm{P} \leq 0.05, * * \mathrm{P} \leq 0.01, * * * \mathrm{P} \leq 0.001)$. The statistical analysis used is the one-way ANOVA with post-hoc Dunnett test at significance level $\alpha=0.05$ (Color figure online)

results of MTT and the number of cells after the multiday incubation (coefficient of determination $\mathrm{R}^{2}<0.30$, Figure ESM-CYTOX-3).

\section{Effects of the AWL3020 Compound on Colony Formation}

Further, we evaluated the influence of AWL3020 on the ability of cells to form colonies. In this test, only cancer cells ( 5 cell lines, concentrations $25-100 \mu \mathrm{M}$ ) were subject to analysis. This is because normal cells did not form colonies in the particular testing conditions (seeding density, time) that we used for the test. The results are graphically presented in Fig. 8 and the numerical data are given in Table ESM-CYTOX-3.

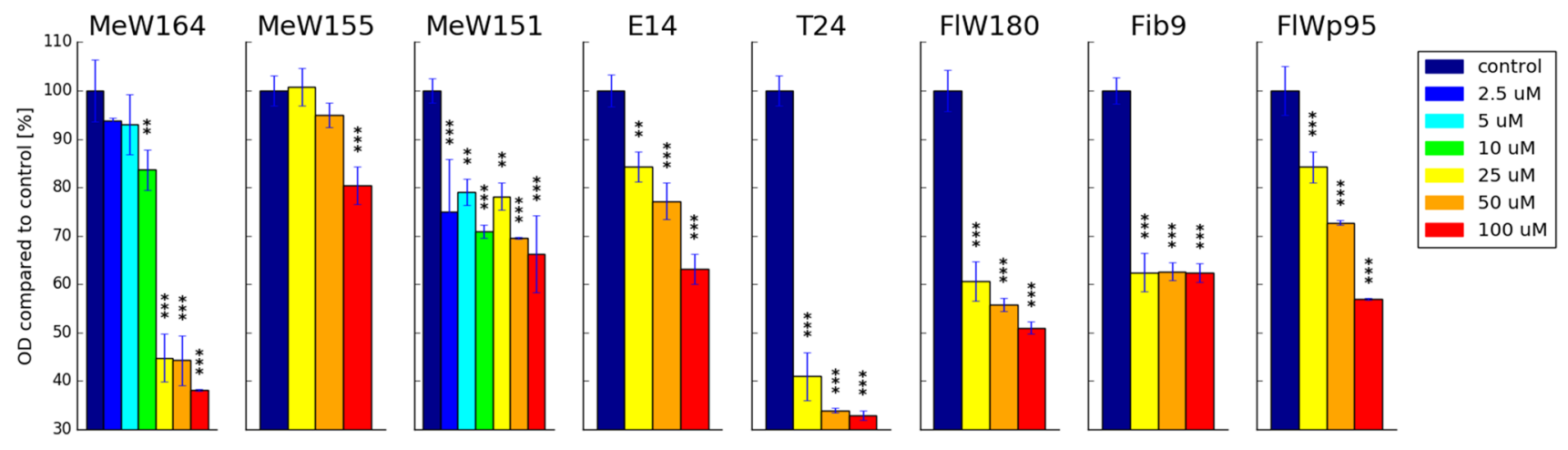

Fig. 7 The effect of AWL3020 on viability of different cell lines as measured in MTT assay. The effect is expressed as percentage of the values found for the control. Bar colouring corresponds to the concentration of AWL3020 as explained in the legend. Cell lines designations given in text. Corresponding numerical values are given in Electronic Supplementary Materials in Table ESM-CYTOX-2. Blue thin bar shows standard deviation. The data come from two independent experiments conducted in triplicate. The asterisks denote statistical significance of the difference between the given value found for the given concentration and the control $(* \mathrm{P} \leq 0.05, * * \mathrm{P} \leq 0.01, * * * \mathrm{P} \leq 0.001)$. The statistical analysis used is the one-way ANOVA with post-hoc Dunnett test at significance level $\alpha=0.05$ (Color figure online) 

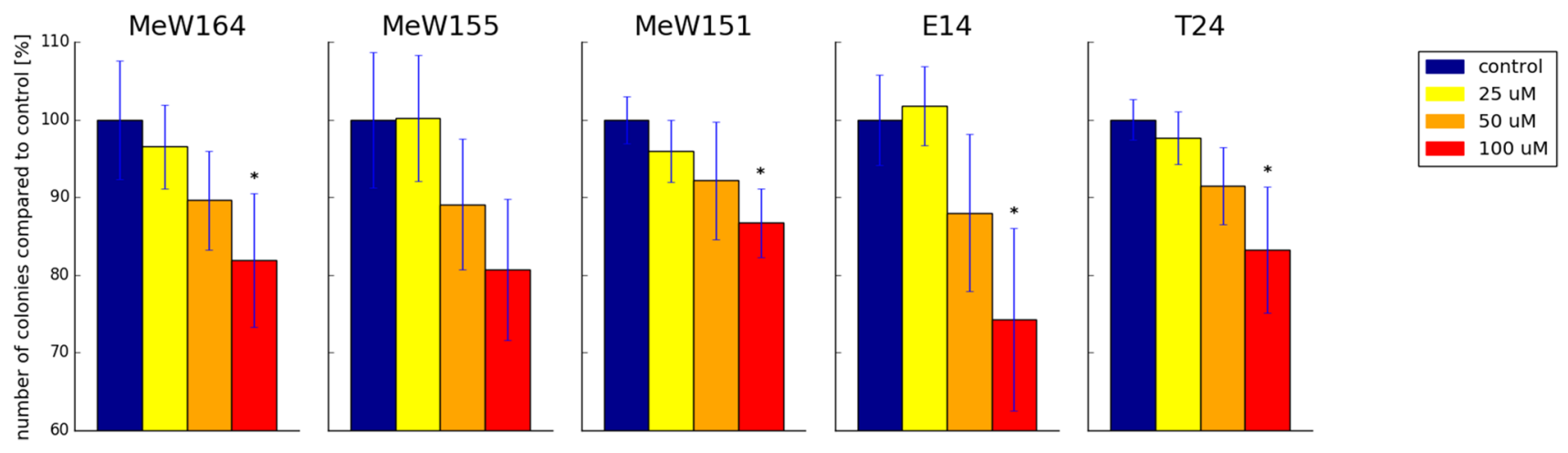

Fig. 8 The effect of AWL3020 on colony formation in different cancer cell lines. The effect is expressed as percentage of the values found for the control. Bar colouring corresponds to the concentration of AWL3020 as explained in the legend. Cell lines designations given in text. Corresponding numerical values are given in Electronic Supplementary Materials in Table ESM-CYTOX-3. Blue thin bar shows

Here, we found statistically significant differences in colony formation only at $100 \mu \mathrm{M}$ concentration. It was however not observed for MeW155 for which none of the results is different than the control (at $\alpha=0.05$ ). Leaving aside this cell line, we see that the results for remaining cell lines are essentially identical (no difference at $\alpha=0.05$, Listing ESMCYTOX-3), being $85 \pm 5 \%$ of the control on average.

\section{Impact on Proliferation Index}

As the last element of cytotoxicity testing we determined the impact of AWL3020 on the Ki-67 index. The protein is a marker for proliferating cells, as it is present in the cell during all phases of the cell cycle $\left(G_{1}, S, G_{2}, M\right)$, but it is standard deviation. The data come from two independent experiments conducted in triplicate. The asterisks denote statistical significance of the difference between the given value found for the given concentration and the control $(* \mathrm{P} \leq 0.05, * * \mathrm{P} \leq 0.01, * * * \mathrm{P} \leq 0.001)$. The statistical analysis used is the one-way ANOVA with post-hoc Dunnett test at significance level $\alpha=0.05$ (Color figure online)

undetectable with the resting state $\left(\mathrm{G}_{0}\right.$ phase). In this test three cell lines ( 2 cancer and 1 normal one) were incubated in the presence of $25-100 \mu \mathrm{M}$ of AWL3020. The results are graphically presented in Fig. 9 and the numerical data are given in Table ESM-CYTOX-4.

For MeW151 cell line, a statistically significant influence of AWL3020 on proliferation index is found for as low as $25 \mu \mathrm{M}$ concentration of the compound. In the highest concentration, AWL3020 reduces the proliferation index to $38 \pm 3 \%$ (control value: $72 \pm 3 \%$ ). Another cancer cell line, $\mathrm{T} 24$, is less sensitive with regard to the proliferation index. In our tests it displayed a significant reduction of the index just at $50 \mu \mathrm{M}$ concentration of AWL3020. With $100 \mu \mathrm{M}$, the index was $59 \pm 10 \%$ (control value: $88 \pm 10 \%$ ). The normal
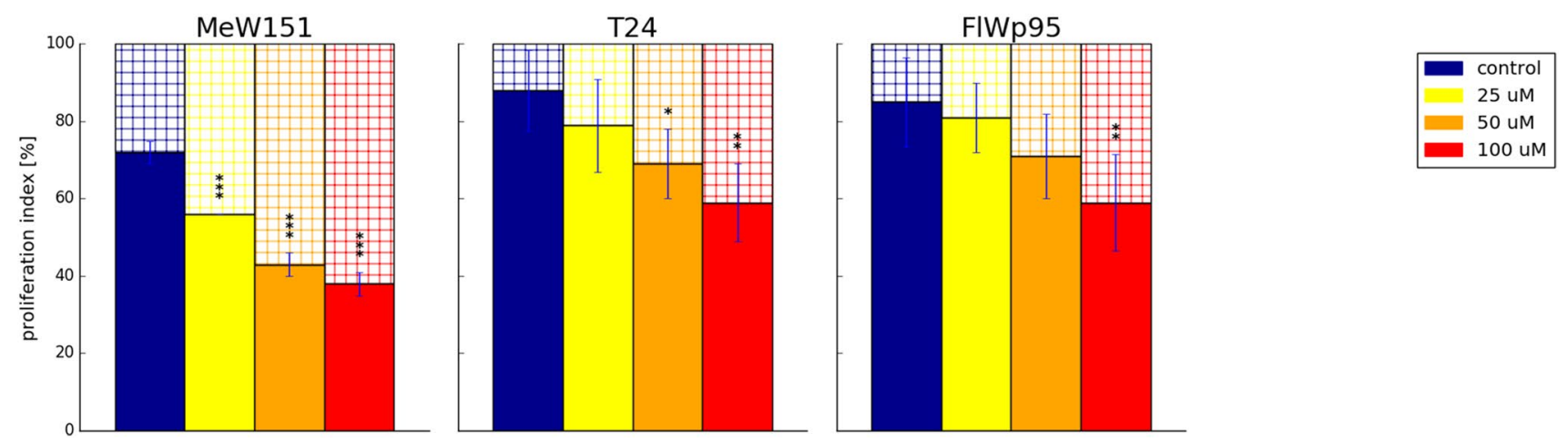

Fig. 9 The effect of AWL3020 on cell proliferation in different cell lines expressed as proliferation index. The effect is expressed as percentage of the values found for the control. Bar colouring corresponds to the concentration of AWL3020 as explained in the legend. The solid bars represent cells that express the $\mathrm{Ki}-67$ protein, while the gridded bars indicate cells that do not express this protein. Cell lines designations given in text. Corresponding numerical values are given in Elec- tronic Supplementary Materials in Table ESM-CYTOX-4. Blue thin bar shows standard deviation. The data come from two independent experiments conducted in triplicate. The asterisks denote statistical significance of the difference between the given value found for the given concentration and the control $(* \mathrm{P} \leq 0.05, * * \mathrm{P} \leq 0.01, * * * \mathrm{P} \leq 0.001)$. The statistical analysis used is the one-way ANOVA with post-hoc Dunnett test at significance level $\alpha=0.05$ (Color figure online) 
cell line, FlWp95, was found significantly sensitive only at $100 \mu \mathrm{M}$, with the index value of $59 \pm 13 \%$ (control value: $85 \pm 12 \%)$.

\section{Discussion}

The compound presented here, AWL3020, is a hybrid peptide created by simple joining of $\delta \mathrm{OR}$ and NK1R pharmacophoric sequences. Consistently with the design, the compound displays high $\delta \mathrm{OR}$ affinity and a rather low $\mu \mathrm{OR}$ binding. On the other hand, contrary to the design assumptions, AWL3020 has only very poor affinity for NK1R. We have also found that AWL3020 produces a relatively strong analgesic effect in vivo. Regarding the effects on cells, as desired, our compound has no pro-proliferative action. In fact, it displays some antiproliferative effects in higher concentrations which is however not selective with respect to normal or cancer cells.

Regarding the opioid affinity and analgesic action, the reported results are not surprising. The sequence of $\delta \mathrm{OR}$ agonist produces an opioid affinity within reasonable boundaries $\left(\mathrm{IC}_{50}=29.5 \mathrm{nM}\right)$ compared to the parent opioid compound. This in turn results in a relatively strong analgesic effect. What must not be unnoticed, the effect is significantly less pronounced than in the case of a gold standard analgesic, morphine. This is consistent with the receptor affinity profile of our derivative (very low $\mu \mathrm{OR}$ affinity and reasonable $\delta$ OR binding). Notably, AWL3020 is weaker an analgesic than our previously reported hybrid JZ031, which additionally was characterized by a fast onset of analgesic activity (Dyniewicz et al. 2017).

That our derivative does not have appreciable NK1R affinity is somehow unexpected given that AWL3020 is created based on a slightly modified sequence of the established NK1R antagonist, spantide I. It might mean that either this slight modification decreases NK1R affinity or this decrease is associated with the presence of the opioid part.

Considering the first of these options, let us recall here that AWL3020 contains C-terminal fragment '...D-PhePhe-D-Phe-Leu-Leu- $\mathrm{NH}_{2}$ ', which is based on the spantide I sequence whose counterpart fragment is '...D-Trp-Phe-DTrp-Leu-Leu- $\mathrm{NH}_{2}{ }^{\text {' }}$. The change in sequence, D-Phe ${ }^{7}$ instead of D-Trp ${ }^{7}$ and D-Phe ${ }^{9}$ instead of D-Trp ${ }^{9}$, is rather conservative in nature (bulky hydrophobic side-chains) and it was not expected to produce a significant change in affinity. To the best of our knowledge, peptides with exact '...D-PhePhe-D-Phe-Leu-Leu- $\mathrm{NH}_{2}$ ' sequence have not been reported so far except for a report of AA3052 by Kowalczyk et al. (Kowalczyk et al. 2016, 2018) who however did not evaluate the receptor affinity but inferred that the compound acts via NK1R based on functional studies. On the other hand, early works on structure-activity relationships of Substance
$\mathrm{P}$ analogues revealed that various derivatives with $\mathrm{D}-\mathrm{Phe}^{7}$ and/or D-Phe ${ }^{9}$ modifications were able to maintain reasonable NK1R affinity and antagonism (Folkers et al. 1981; Bailey and Jordan 1984; Dutta 1993). Regarding the second option, that the low NK1R affinity is due to the presence of the opioid part, previous reports on the opioid-(anti)tachykinin hybrids provide useful material for comparisons. In the past many papers dealing with such compounds were reported, including a few with our contributions (Matalinska et al. 2013; Dyniewicz et al. 2017). Yanamoto and co-workers (Yamamoto et al. 2007) considered a series of compounds, where an enkephalin fragment was joined with mixed organic/peptide antitachikinin pharmacophore, H-TyrD-Ala-Gly-Phe-Xxx-Pro-Leu-Trp-O-3,5-Bzl $\left(\mathrm{CF}_{3}\right)_{2}$ (Bzlbenzyl, $\mathrm{Xxx}$ - various amino acids). The NK1R inhibition constant $\left(\mathrm{K}_{\mathrm{i}}\right)$ values varied only slightly, between 0.2 and $3.0 \mathrm{nM}$. A much more pronounced variation was observed in another paper by these authors (Yamamoto et al. 2008), where they considered derivatives of H-Tyr-D-Ala-Gly-PhePro-Leu-Trp-... with modifications of the C-terminal part directly involved in the interactions with the NK1R. Here, $\mathrm{K}_{\mathrm{i}}$ values spanned from as low as $0.0046 \mathrm{nM}$ to $100 \mathrm{nM}$. Further analogues in which the opioid part was cyclized were reported (Yamamoto et al. 2010) and here, the derivatives in which -Pro-Leu-Trp-NH-3,5-Bzl $\left(\mathrm{CF}_{3}\right)_{2}$ fragment was left outside the cycle had subnanomolar $\mathrm{K}_{\mathrm{i}}$ values. If however, only the Trp-NH-3,5-Bzl( $\left(\mathrm{CF}_{3}\right)_{2}$ fragment was exocyclic, a significant affinity drop was observed. In another contribution by this group (Yamamoto et al. 2011), modifications of the C-terminal part (NK1R pharmacophore) resulted in variations of three orders of magnitude range, still however the weakest derivatives had nanomolar $\mathrm{K}_{\mathrm{i}}$ values. In another series of hybrids (Giri et al. 2015), the focus was on modifying the $1^{\text {st }}$ and $4^{\text {th }}$ position of the enkephalin sequence. These substitutions did not affect the NK1R affinity and the $\mathrm{K}_{\mathrm{i}}$ values for all derivatives in the paper were of a few nanomoles. The structure of the enkephalin-(anti)tachykinin hybrid was skilfully truncated (Nair et al. 2013, 2015) what allowed for finding a very short compound of structure, H-Tyr-D-Ala-Trp-O-3,5-Bzl $\left(\mathrm{CF}_{3}\right)_{2}\left(\mathrm{NK} 1 \mathrm{R} \mathrm{K} \mathrm{K}_{\mathrm{i}}=0.004 \mathrm{nM}\right)$ in which opioid and NK1R pharmacophores significantly overlapped. A series of structural changes that led to this derivative, shortening of the sequence and substitutions, resulted in NK1R affinity fluctuations of two to three orders of magnitude, but still all reported $\mathrm{K}_{\mathrm{i}}$ values were subnanomolar. Another group of chimeras found by fusing both pharmacophores so that they partially overlapped, included Dmt-DALDA (Riba et al. 2002) sequence as the opioid pharmacophore, with H-Dmt-D-Arg-Aba-Gly-N-3,5-Bzl( $\left(\mathrm{CF}_{3}\right)_{2}$ being the first example (Ballet et al. 2011). This compound showed very good NK1R affinity $\left(\mathrm{K}_{\mathrm{i}}=0.5 \mathrm{nM}\right)$. Modifications of the $\mathrm{N}$-terminal part resulted in much variation of affinity even up to micromolar values (Guillemyn et al. 2015; 
Starnowska et al. 2017). It is also 3-arylpiperidine-based NK1R pharmacophores that were successfully introduced into the discussed type of hybrids (Betti et al. 2015). In that study, low nanomolar $\mathrm{K}_{\mathrm{i}}$ values for NK1R affinity were observed, notwithstanding changes in the opioid part.

Overall, in the above summarized literature data, NK1R affinity significant drops were associated with changes of the C-terminal, neurokinin-1 pharmacophoric part and not with the modifications in the opioid part. Whether this is the case for AWL3020 cannot be stated as certain without further studies. A probable answer to this problem might come from molecular modelling using recently published structures of the receptor (Yin et al. 2018; Schöppe et al. 2019; Chen et al. 2019b). We did not attempt such modelling, as the structures were unavailable at the time our study was being performed. Further, the structures are solved in the present of small molecular ligands, so proper modelling will certainly require a careful validation of the binding site for a peptide ligand, in particular against experimental hints from the literature (Pellegrini et al. 2001; Valentin-Hansen et al. 2014).

Regarding the influence of AWL3020 on cancer and normal cells, the compound displays no pro-proliferative action in any of the tests used. In fact, for several combinations cell line/assay, some antiproliferative activity could be found. For instance, incubation with AWL3020 reduced the number of MeW164 cancer cells (compared to control) with $\mathrm{EC}_{50}=46.27 \mu \mathrm{M}$. This cell line was also found very sensitive to action of AWL3020 in MTT assays $\left(\mathrm{EC}_{50}=37.78 \mu \mathrm{M}\right)$. However, such activity levels were not found with other cell lines and excluding MeW164 from comparisons, we found no strong, general selectivity in the action of AWL3020 on cancer and normal cells.

So far, the only reports on the influence that hybrids made of opioid and NK1R pharmacophores exert on the proliferation of cancer or normal cells came only from our group. In our previous contribution, we have disclosed compound AA3266 that showed nanomolar opioid affinities and hNK1R affinity with $\mathrm{K}_{\mathrm{i}}=180 \mathrm{nM}$ (Matalinska et al. 2013). At the same time it showed significant selectivity in influencing the proliferation of cancer and normal cell lines (similar set to the one studied here).

Other hybrid opioid peptides assessed as to their action on cancer cells were made of $\mu$-opioid tripeptide sequence and trans-1-cinnamylpiperazine moiety (Laskowska et al. 2017). A significant antiproliferative effect on cells was reported. The discussed high affinity $\mu \mathrm{OR}$ ligands exhibited much greater impact on cell viability in 2D and 3D cell cultures of pancreatic cancer than a reference drug gemcitabine. The effect was however not selective and normal cells were also affected to a high degree. The authors did not investigated a putative mechanism of the antiproliferative action of their compounds.
Our working assumption was that introduction of NK1R antagonistic component would result in some antiproliferative (cytotoxic) activity against cancer cells. AWL3020 however turned out to have very low NK1R affinity. The question arises of whether the observed antiproliferative action could be associated with this only low affinity. The reports of antitumour activity of NK1R antagonists dealt with high affinity antagonists, including aprepitant, L-733,060 or L-732,138. These compounds, which are nanomolar binders of the NK1R, were shown to exert antiproliferative influence on various cancer cells lines with $\mathrm{IC}_{50}$ values of several to several dozen micromoles, depending on the cell line type (Muñoz and Rosso 2010; Muñoz et al. 2010, 2015; Rosso et al. 2012; Munoz and Covenas 2012; 2016, 2019). Further, this activity was found to occur via the receptor and by the induction of cell apoptosis. Our low-affinity hybrid achieves similar effective concentration only with a melanoma cell line, MeW164. In this case, we have a distinct proportion of NK1R affinity and toxicity: nanomolar affinity/micromolar cytostaticity in the previous reports, and micromolar affinity / micromolar cytostaticity for AWL3020. This could be indicative of some other mechanism being at work here, e.g. a one via classical or non-classical opioid receptors.

Even though opioids were often found to have pro-proliferative effects on cancer cells, other reports brought opposing findings (Tegeder et al. 2003; Tegeder and Geisslinger 2004; Chen et al. 2008; Lazarczyk et al. 2010; Lennon et al. 2014; Gonzalez-Nunez et al. 2014; Kim et al. 2016). This discrepancy in results stems from different opioid types, cell lines, modes and scheme of administration and probably other factors in a particular study. They also reflect complexity of the effects opioids have on cell growth, survival and death (Tegeder and Geisslinger 2004). There were different suggestions as to whether these actions might be associated with opioid receptors of GPCR family or with other non-classical opioid receptors. A thoroughly explored phenomenon is the anti-proliferative effect of $\left[\mathrm{Met}^{5}\right]$-enkephalin (called otherwise opioid growth factor, OGF) exerted via OGF receptors (OGFr) (McLaughlin and Zagon 2012). These intracellular binding sites do not appreciably bind many typical opioids, like DAMGO, DPDPE, Dynorphin A or morphine, while binding $\left[\mathrm{Met}^{5}\right]$-enkephalin. Much evidence has been reported that this OGF-OGFr interaction inhibits proliferation in both normal and cancer cells (McLaughlin and Zagon 2012). The mechanism behind this effect involves regulation of cell cycle $\left(\mathrm{G}_{0} / \mathrm{S}\right.$ phases $)$ and induction of cyclin dependent inhibitory kinases p16 and/ or p21 expression. Further research on AWL3020 must certainly address involvement of the classical and non-classical opioid receptor pathways in its effects on cells.

Interestingly, there are some reports on -D-Phe-Phe-DPhe-hexapeptides (or derivatives) exhibiting relatively strong antifungal activity (Kundu et al. 2000, 2002). Whether the 
toxicity of AWL3020 could have anything in common with this activity is hard to even speculate on, as the mechanisms behind microbial and mammalian cytotoxicities are often utterly different. However, for the sake of comprehensiveness let us note it at this place.

In general, the described antiproliferative action of AWL3020 is not very high. The effective antiproliferative concentrations seem unlikely to be reached with normal administration routines, in particular when one considers metabolic instability of peptides. It means that this antiproliferative action of AWL3020 cannot be expected to be either a problem in analgesic treatment or an advantage from the point of view of auxiliary anticancer properties. The latter could be achieved only after further modifications of AWL3020 structure that could bring more NK1R affinity so that selective anticancer activity would follow. Else, if a mechanism different than via NK1R could be elucidated, by which AWL3020 exerts its antiproliferative action, one could attempt to optimize the compounds' structure to obtain anticancer effects via this putative mechanism. Anywise, it is clear that AWL3020 structure requires more work, as the design assumptions were only partially realized. That the search of analgesic compounds with adjuvant anticancer properties (Matalinska et al. 2013) is still worth pursuing emerges from a recent study (Ge et al. 2019) where the authors were able to demonstrate that a NK1R antagonist SR140333 exerts anticancer action in mice xenografted with human myeloid leukemia cells and further produces a potent antinociceptive effect in leukemia-induced bone pain model.

\section{Conclusions}

In the present paper we have reported the design, synthesis and in vitro evaluation of AWL3020, a hybrid peptide made of delta opioid agonist and neurokinin-1 antagonist sequences. The compound displayed high $\delta \mathrm{OR}$ binding, but contrary to the design assumptions only a very poor affinity for the NK1R. As strived for, the novel hybrid has no proproliferative action on either cancer or normal cells. In larger concentrations, it displays antiproliferative activity which is however not much selective.

Acknowledgements This research was supported by a scholarship from the European Social Fund, Human Capital Operational Programme, UDA-POKL.08.02.01-14-041/09. The calculations were performed at Interdisciplinary Centre for Mathematical and Computational Modelling (ICM), Warsaw, Poland (computational grant G63-10) and at Świerk Computing Centre, National Centre for Nuclear Research, Świerk, Poland.

Author Contributions conceptualization JM; methodology JM, AK, PK, PFJL, JD; investigation, JM, PK, PFJL, AM; writing-original draft preparation, JM; writing — review and editing, JM, PFJL; project administration, JM; funding acquisition, JM.

\section{Compliance with Ethical Standards}

Conflict of interest The authors declare no conflict of interest.

Ethical Approval All animal experiments were approved by the IV Local Ethics Committee for Experiments on Animals in Warsaw, Poland.

Open Access This article is licensed under a Creative Commons Attribution 4.0 International License, which permits use, sharing, adaptation, distribution and reproduction in any medium or format, as long as you give appropriate credit to the original author(s) and the source, provide a link to the Creative Commons licence, and indicate if changes were made. The images or other third party material in this article are included in the article's Creative Commons licence, unless indicated otherwise in a credit line to the material. If material is not included in the article's Creative Commons licence and your intended use is not permitted by statutory regulation or exceeds the permitted use, you will need to obtain permission directly from the copyright holder. To view a copy of this licence, visit http://creativecommons.org/licenses/by/4.0/.

\section{References}

Aich A, Gupta P, Gupta K (2016) Could perioperative opioid use increase the risk of cancer progression and metastases? Int Anesthesiol Clin 54:e1-e16. https://doi.org/10.1097/AIA.0000000000 000112

Bailey SJ, Jordan CC (1984) A study of [d-Pro2, d-Phe7, d-Trp9]substance $\mathrm{P}$ and [d-Trp 7,9]-substance $\mathrm{P}$ as tachykinin partial agonists in the rat colon. Br J Pharmacol 82:441-451. https://doi. org/10.1111/j.1476-5381.1984.tb10779.x

Ballet S, Feytens D, Buysse K et al (2011) Design of novel neurokinin 1 receptor antagonists based on conformationally constrained aromatic amino acids and discovery of a potent chimeric opioid agonist-neurokinin 1 receptor antagonist. J Med Chem 54:24672476. https://doi.org/10.1021/jm1016285

Benyamin R, Trescot AM, Datta S et al (2008) Opioid complications and side effects. Pain Physician 11:S105-S120

Betti C, Starnowska J, Mika J et al (2015) Dual alleviation of acute and neuropathic pain by fused opioid agonist-neurokinin 1 antagonist peptidomimetics. ACS Med Chem Lett 6:1209-1214. https://doi. org/10.1021/acsmedchemlett.5b00359

Bimonte S, Barbieri A, Rea D et al (2015) Morphine promotes tumor angiogenesis and increases breast cancer progression. Biomed Res Int 2015:1-8. https://doi.org/10.1155/2015/161508

Brady LS, Holtzman SG (1982) Analgesic effects of intraventricular morphine and enkephalins in nondependent and morphinedependent rats. J Pharmacol Exp Ther 222:190-197

Brinkman D, Wang JH, Redmond HP (2018) Morphine as a treatment of cancer-induced pain-is it safe? A review of in vivo studies and mechanisms. Naunyn Schmiedebergs Arch Pharmacol 391:1169 1178. https://doi.org/10.1007/s00210-018-1565-6

Bubeník J, Barešová M, Viklický V et al (1973) Established cell line of urinary bladder carcinoma (T24) containing tumour-specific antigen. Int J Cancer 11:765-773. https://doi.org/10.1002/ijc.29101 10327

Chen Y, Law P, Loh H (2008) The other side of the opioid story: modulation of cell growth and survival signaling. Curr Med Chem 15:772-778. https://doi.org/10.2174/092986708783955518

Chen Y, Qin Y, Li L et al (2017) Morphine can inhibit the growth of breast cancer MCF-7 cells by arresting the cell cycle and 
inducing apoptosis. Biol Pharm Bull 40:1686-1692. https://doi. org/10.1248/bpb.b17-00215

Chen DT, Pan JH, Chen YH et al (2019a) The mu-opioid receptor is a molecular marker for poor prognosis in hepatocellular carcinoma and represents a potential therapeutic target. Br J Anaesth 122:e157-e167. https://doi.org/10.1016/j.bja.2018.09.030

Chen S, Lu M, Liu D et al (2019b) Human substance P receptor binding mode of the antagonist drug aprepitant by NMR and crystallography. Nat Commun 10:638. https://doi.org/10.1038/s4146 7-019-08568-5

Collection ATC MTT Cell Proliferation Assay Instruction Guide (2016) https://www.lgcstandards-atcc.org/ /media/DA5285A1F5 2C414E864C966FD78C9A79.ashx. Accessed 17 Apr 2019

Dutta A (1993) Tachykinins substance P, neurokinin A and neurokinin B. Small Peptides, Chemistry. Biology and Clinical Studies. Elsevier Publishers B.V, Amsterdam, pp 355-414

Dyniewicz J, Lipiński PFJ, Kosson P et al (2017) Hydrazone linker as a useful tool for preparing chimeric peptide/nonpeptide bifunctional compounds. ACS Med Chem Lett 8:73-77. https://doi. org/10.1021/acsmedchemlett.6b00381

Fenalti G, Zatsepin NA, Betti C et al (2015) Structural basis for bifunctional peptide recognition at human $\delta$-opioid receptor. Nat Struct Mol Biol 22:265-268. https://doi.org/10.1038/nsmb.2965

Folkers K, Hörig J, Rosell S, Björkroth U (1981) Chemical design of antagonists of substance P. Acta Physiol Scand 111:505-506. https://doi.org/10.1111/j.1748-1716.1981.tb06771.x

Garnier A, Vykoukal J, Hubertus J et al (2015) Targeting the neurokinin-1 receptor inhibits growth of human colon cancer cells. Int J Oncol 47:151-160. https://doi.org/10.3892/ijo.2015.3016

Gavériaux-Ruff C, Kieffer BL (2011) Delta opioid receptor analgesia. Behav Pharmacol 22:405-414. https://doi.org/10.1097/FBP.0b013 e 32834a1f2c

Ge C, Huang H, Huang F et al (2019) Neurokinin-1 receptor is an effective target for treating leukemia by inducing oxidative stress through mitochondrial calcium overload. Proc Natl Acad Sci 116:19635-19645. https://doi.org/10.1073/pnas.1908998116

Gether U, Johansen TE, Snider RM et al (1993) Different binding epitopes on the NK1 receptor for substance P and a non-peptide antagonist. Nature 362:345-348. https://doi.org/10.1038/36234 $5 \mathrm{a} 0$

Giri AK, Apostol CR, Wang Y et al (2015) Discovery of novel multifunctional ligands with $\mu / \delta$ opioid agonist/neurokinin-1 (NK1) antagonist activities for the treatment of pain. J Med Chem 58:8573-8583. https://doi.org/10.1021/acs.jmedchem.5b01170

Gonzalez-Nunez V, Noriega-Prieto JA, Rodríguez RE (2014) Morphine modulates cell proliferation through mir133b \& mir128 in the neuroblastoma SH-SY5Y cell line. Biochim Biophys Acta Mol Basis Dis 1842:566-572. https://doi.org/10.1016/j.bbadi s.2014.01.003

Guillemyn K, Kleczkowska P, Lesniak A et al (2015) Synthesis and biological evaluation of compact, conformationally constrained bifunctional opioid agonist: neurokinin-1 antagonist peptidomimetics. Eur J Med Chem 92:64-77

Harford-Wright E, Lewis KM, Vink R (2013) The potential for substance $\mathrm{P}$ antagonists as anti-cancer agents in brain tumours. Recent Pat CNS Drug Discov 8:13-23

Janecka A, Fichna J, Janecki T (2004) Opioid Receptors and their ligands. Curr Top Med Chem 4:1-17. https://doi. org/10.2174/1568026043451618

Kim JY, Ahn HJ, Kim JK et al (2016) Morphine suppresses lung cancer cell proliferation through the interaction with opioid growth factor receptor. Anesth Analg 123:1429-1436. https://doi.org/10.1213/ ANE.0000000000001293

Kowalczyk A, Kleczkowska P, Rękawek M et al (2016) Biological evaluation and molecular docking studies of AA3052, a compound containing a $\mu$-selective opioid peptide agonist DALDA and d-Phe-Phe-d-Phe-Leu-Leu-NH2, a substance P analogue. Eur J Pharm Sci 93:11-20. https://doi.org/10.1016/j.ejps.2016.07.009

Kowalczyk A, Kleczkowska P, Konop M et al (2018) Determination of the anti-inflammatory properties and analgesic activity of the AA3052 chimeric peptide against CFA-induced inflammatory pain. Anim Sci Pap Rep 36:219-240

Kundu B, Rastogi S, Batra S et al (2000) Combinatorial approach to lead optimization of a novel hexapeptide with antifungal activity. Bioorg Med Chem Lett 10:1779-1781. https://doi.org/10.1016/ S0960-894X(00)00343-7

Kundu B, Srinivasan T, Kesarwani AP et al (2002) Identification of novel antifungal nonapeptides through the screening of combinatorial peptide libraries based on a hexapeptide motif. Bioorg Med Chem Lett 12:1473-1476. https://doi.org/10.1016/S0960 -894X(02)00174-9

Largent-Milnes T, Yamamoto T, Nair P et al (2010) Spinal or systemic TY005, a peptidic opioid agonist/neurokinin 1 antagonist, attenuates pain with reduced tolerance. Br J Pharmacol 161:986-1001. https://doi.org/10.1111/j.1476-5381.2010.00824.x

Laskowska AK, Puszko AK, Sosnowski P et al (2017) Opioid tripeptides hybridized with trans-1-cinnamylpiperazine as proliferation inhibitors of pancreatic cancer cells in two- and three-dimensional in vitro models. ChemMedChem 12:1637-1644. https://doi. org/10.1002/cmdc.201700453

Lazarczyk M, Matyja E, Lipkowski AW (2010) A comparative study of morphine stimulation and biphalin inhibition of human glioblastoma T98G cell proliferation in vitro. Peptides 31:1606-1612. https://doi.org/10.1016/j.peptides.2010.05.002

Lennon FE, Moss J, Singleton PA (2012) The $\mu$-opioid receptor in cancer progression. Anesthesiology 116:940-945. https://doi. org/10.1097/ALN.0b013e31824b9512

Lennon FE, Mirzapoiazova T, Mambetsariev B et al (2014) The Mu opioid receptor promotes opioid and growth factor-induced proliferation, migration and epithelial mesenchymal transition (EMT) in human lung cancer. PLoS ONE 9:e91577. https://doi.org/10.1371/ journal.pone.0091577

Matalinska J, Skurzak H, Markowicz S et al (2013) Original article opioid agonist: tachykinin antagonist as a new analgesic with adjuvant anticancer properties. Folia Neuropathol 2:132-139. https://doi.org/10.5114/fn.2013.35956

McLaughlin PJ, Zagon IS (2012) The opioid growth factor-opioid growth factor receptor axis: homeostatic regulator of cell proliferation and its implications for health and disease. Biochem Pharmacol 84:746-755. https://doi.org/10.1016/j.bcp.2012.05.018

Money S, Garber B (2018) Management of cancer pain. Curr Emerg Hosp Med Rep 6:141-146. https://doi.org/10.1007/s4013 8-018-0170-9

Morris GM, Huey R, Lindstrom W et al (2009) AutoDock4 and AutoDockTools4: automated docking with selective receptor flexibility. J Comput Chem 30:2785-2791. https://doi.org/10.1002/jcc.21256

Muñoz M, Coveñas R (2016) Neurokinin-1 receptor antagonists as antitumor drugs in gastrointestinal cancer: a new approach. Saudi J Gastroenterol 22:260. https://doi.org/10.4103/1319-3767.18760 1

Muñoz M, Coveñas R (2019) Neurokinin-1 receptor antagonists as anticancer drugs. Lett Drug Des Discov 16:1110-1129. https:// doi.org/10.2174/1570180816666190221091955

Muñoz M, Rosso M (2010) The NK-1 receptor antagonist aprepitant as a broad spectrum antitumor drug. Invest New Drugs 28:187-193. https://doi.org/10.1007/s10637-009-9218-8

Munoz M, Covenas R (2012) NK-1 receptor antagonists: a new generation of anticancer drugs. Mini-Rev Med Chem 12:593-599. https ://doi.org/10.2174/138955712800626692

Muñoz M, Rosso M, Robles-Frias MJ et al (2010) The NK-1 receptor is expressed in human melanoma and is involved in the antitumor action of the NK-1 receptor antagonist aprepitant on melanoma 
cell lines. Lab Investig 90:1259-1269. https://doi.org/10.1038/ labinvest.2010.92

Muñoz M, Coveñas R, Esteban F, Redondo M (2015) The substance $\mathrm{P} / \mathrm{NK}-1$ receptor system: NK-1 receptor antagonists as anti-cancer drugs. J Biosci 40:441-463. https://doi.org/10.1007/s1203 8-015-9530-8

Nair P, Yamamoto T, Largent-Milnes TM et al (2013) Truncation of the peptide sequence in bifunctional ligands with mu and delta opioid receptor agonist and neurokinin 1 receptor antagonist activities. Bioorg Med Chem Lett 23:4975-4978. https://doi.org/10.1016/j. bmcl.2013.06.065

Nair P, Yamamoto T, Cowell S et al (2015) Discovery of tripeptidederived multifunctional ligands possessing delta/mu opioid receptor agonist and neurokinin 1 receptor antagonist activities. Bioorg Med Chem Lett 25:3716-3720. https://doi.org/10.1016/j. bmcl.2015.06.030

Nguyen J, Luk K, Vang D et al (2014) Morphine stimulates cancer progression and mast cell activation and impairs survival in transgenic mice with breast cancer. Br J Anaesth 113:i4-i13. https:// doi.org/10.1093/bja/aeu090

Pellegrini M, Bremer AA, Ulfers AL et al (2001) Molecular characterization of the substance P-neurokinin-1 receptor complex. J Biol Chem 276:22862-22867. https://doi.org/10.1074/jbc.M1010 57200

Portenoy RK, Ahmed E (2018) Cancer pain syndromes. Hematol Oncol Clin North Am 32:371-386. https://doi.org/10.1016/j. hoc.2018.01.002

Riba P, Ben Y, Nguyen T et al (2002) [Dmt ${ }^{1}$ ]DALDA is highly selective and potent at mu opioid receptors, but is not cross-tolerant with systemic morphine. Curr Med Chem 9:31-39. https://doi. org/10.2174/0929867023371445

Rosso M, Muñoz M, Berger M (2012) the role of neurokinin-1 receptor in the microenvironment of inflammation and cancer. Sci World J 2012:1-21. https://doi.org/10.1100/2012/381434

Schöppe J, Ehrenmann J, Klenk C et al (2019) Crystal structures of the human neurokinin 1 receptor in complex with clinically used antagonists. Nat Commun 10:17. https://doi.org/10.1038/s4146 7-018-07939-8

Starnowska J, Costante R, Guillemyn K et al (2017) Analgesic properties of opioid/NK1 multitarget ligands with distinct in vitro profiles in naive and chronic constriction injury (CCI)-mice. ACS Chem Neurosci. https://doi.org/10.1021/acschemneuro.7b00226

Tegeder I, Geisslinger G (2004) Opioids as modulators of cell death and survival-unraveling mechanisms and revealing new indications. Pharmacol Rev 56:351-369. https://doi.org/10.1124/ pr.56.3.2
Tegeder I, Grösch S, Schmidtko A et al (2003) G protein-independent G1 cell cycle block and apoptosis with morphine in adenocarcinoma cells: involvement of p53 phosphorylation. Cancer Res 63:1846-1852

Tuerxun H, Cui J (2019) The dual effect of morphine on tumor development. Clin Transl Oncol 21:695-701. https://doi.org/10.1007/ s12094-018-1974-5

Valentin-Hansen L, Park M, Huber T et al (2014) Mapping substance $\mathrm{P}$ binding sites on the neurokinin-1 receptor using genetic incorporation of a photoreactive amino acid. J Biol Chem 289:1804518054. https://doi.org/10.1074/jbc.M113.527085

Yaksh TL, Rudy TA (1976) Chronic catheterization of the spinal subarachnoid space. Physiol Behav 17:1031-1036. https://doi. org/10.1016/0031-9384(76)90029-9

Yamamoto T, Nair P, Davis P et al (2007) Design, synthesis, and biological evaluation of novel bifunctional C-terminal-modified peptides for $\delta / \mu$ opioid receptor agonists and neurokinin- 1 receptor antagonists. J Med Chem 50:2779-2786. https://doi.org/10.1021/ JM061369N

Yamamoto T, Nair P, Vagner J et al (2008) A structure-activity relationship study and combinatorial synthetic approach of C-terminal modified bifunctional peptides that are $\delta / \mu$ opioid receptor agonists and neurokinin 1 receptor antagonists. J Med Chem 51:1369-1376. https://doi.org/10.1021/jm070332f

Yamamoto T, Nair P, Jacobsen NE et al (2010) Biological and conformational evaluation of bifunctional compounds for opioid receptor agonists and neurokinin 1 receptor antagonists possessing two penicillamines. J Med Chem 53:5491-5501. https://doi. org/10.1021/jm100157m

Yamamoto T, Nair P, Largent-Milnes TM et al (2011) Discovery of a potent and efficacious peptide derivative for $\delta / \mu$ opioid agonist/ neurokinin 1 antagonist activity with a 2',6'-dimethyl-L-tyrosine: in vitro, in vivo, and NMR-based structural studies. J Med Chem 54:2029-2038. https://doi.org/10.1021/jm101023r

Yin J, Chapman K, Clark LD et al (2018) Crystal structure of the human NK 1 tachykinin receptor. Proc Natl Acad Sci 115:1326413269. https://doi.org/10.1073/pnas.1812717115

Zhang X, Liang Y, Yan Y et al (2018) Morphine: double-faced roles in the regulation of tumor development. Clin Transl Oncol 20:808814. https://doi.org/10.1007/s12094-017-1796-x

Publisher's Note Springer Nature remains neutral with regard to jurisdictional claims in published maps and institutional affiliations. 